\title{
Demonstration of Antifungal Antibodies in Hyperimmune Mouse Ascitic Fluid by Means of Crossed Immunoelectrophoresis
}

\author{
By L. HORNOK AND Á. SZÉCSI \\ Research Institute for Plant Protection, I 525 Budapest, \\ P.O.B. 102, Hungary
}

(Received 27 September 1976; revised 22 November 1976)

INTRODUCTION

The main difficulties encountered in mycoserology are (i) the large number of rabbits required for the serological classification of a single fungal genus and (ii) the identification and quantification of antigens and antibodies in the highly complex fungal system.

Anacker \& Munoz (196I) found the peritoneal fluid of mice immunized with egg albumin in Freund's adjuvant could contain $2 \mathrm{mg}$ antibody nitrogen $\mathrm{ml}^{-1}$, an antibody concentration which is difficult to obtain in rabbit antisera. Immune mouse peritoneal fluid has been used as a source of antibodies for plant, animal and human viruses (e.g. Herrman \& Engle, I958; Reddecliff \& Ludwig, I966; Scott, Kim \& Dale, 1969; Feild \& Kalter, I972; Kiriyama \& Ohsumi, 1973) and for certain bacteria (Thoen \& Karlson, 1970; Bocharova \& Andreeva, 1971) but not in fungus serology.

Axelsen (197I, I973) demonstrated and quantified the antigens in Candida albicans by using immune rabbit sera and the crossed immunoelectrophoresis technique.

There are no reports on the use of immune mouse ascitic fluid in quantitative immunoelectrophoretic procedures. Immune ascitic fluid could be useful in fungal studies but only if the antigen-antibody reactions can be examined by quantitative immunoelectrophoresis. The purpose of our work was to investigate this possibility.

METHODS

Organism. Fusarium culmorum (W. G. Smith) Sacc. strain 22-I2 was maintained in this laboratory.

Preparation of antigen. Potato/glucose broth $(200 \mathrm{~g}$ peeled, sliced potatoes and $20 \mathrm{~g}$

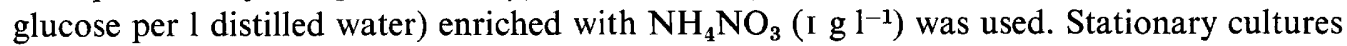
were grown by inoculating $60 \mathrm{ml}$ medium in $300 \mathrm{ml}$ Erlenmeyer flasks with $10^{5}$ conidia and incubating at $25^{\circ} \mathrm{C}$ for $72 \mathrm{~h}$ in the dark. The mycelium was harvested by filtration, washed three times with distilled water, dried between paper towels and stored at $-20{ }^{\circ} \mathrm{C}$. The frozen mycelium was ground with a pestle and mortar, extracted with distilled water (I $\mathrm{ml}$ per I $\mathrm{g}$ wet wt of the mycelium) for $3 \mathrm{~h}$ at $4{ }^{\circ} \mathrm{C}$ and the whole was centrifuged at $5000 \mathrm{~g}$ for $20 \mathrm{~min}$. The supernatant solution was recentrifuged at $60000 \mathrm{~g}$ for $60 \mathrm{~min}$ at $0{ }^{\circ} \mathrm{C}$. Protein was determined by the method of Goa (1953) with human serum albumin as the standard. Before the extract was stored at $-20{ }^{\circ} \mathrm{C}$, its protein content was adjusted to $25 \mathrm{mg} \mathrm{ml}^{-1}$ by overnight dialysis against $\mathrm{O} \cdot \mathrm{I} \mathrm{M}-\mathrm{NaCl}$ solution containing $20 \%(\mathrm{w} / \mathrm{v})$ polyethylene glycol 20000 .

Ascites inducer. Ehrlich Lettre ascites tumour cells were supplied by the Department of Pathological Anatomy, Semmelweis Medical University, Budapest. The tumour line underwent 10 additional mouse passages at this laboratory before use. 
Antibody production. Different immunization schedules were tried. Four groups of 6-weekold female CFLP mice (five per group) obtained from the Laboratory Animal Production Institute, Gödöllö, Hungary, were injected intraperitoneally with equal portions (O I I ml) of the antigen and of Freund's complete adjuvant (Serobacteriological Research and Production Institute 'Human', Budapest, Hungary). Identical booster injections were given I 5 and 29 days later to the first group of mice, 29 and 57 days later to the second group, and 29 and $7 \mathrm{I}$ days later to the third group. Animals in the fourth group received only a single booster injection after $7 \mathrm{I}$ days. Three days after the last antigen injection, $5 \times 10^{6}$ Ehrlich ascites tumour cells in $0.5 \mathrm{ml}$ physiological saline were introduced by the intra-abdominal route. Ten to I 5 days later the animals were killed and the ascitic fluid was collected. Fluids were pooled, and immediately centrifuged at $4000 \mathrm{~g}$ for $30 \mathrm{~min}$ at $4{ }^{\circ} \mathrm{C}$ to pack the cells. Immune ascites pools were stored at $-20^{\circ} \mathrm{C}$ until used.

Immunodiffusion. The crude immune ascites pools were tested for the presence of antibodies in $\mathrm{I} \%(\mathrm{w} / \mathrm{v})$ agarose (REANAL, Budapest, Hungary) dissolved in barbital buffer ( $\mathrm{pH} \mathrm{8.4,} \mathrm{ionic} \mathrm{strength} \mathrm{0.02)} \mathrm{using} \mathrm{a} \mathrm{micro-modification} \mathrm{of} \mathrm{the} \mathrm{Ouchterlony} \mathrm{technique}$ (Ouchterlony \& Nilsson, 1973). After $24 \mathrm{~h}$ incubation at $25^{\circ} \mathrm{C}$, precipitin lines were stained with Coomassie brilliant blue G-250 (Serva, Heidelberg, Germany) as described by Weeke (1973).

Purification and concentration of antibodies. Immunoglobulins from the pools were obtained by $\left(\mathrm{NH}_{4}\right)_{2} \mathrm{SO}_{4}$ precipitation at $50 \%$ saturation. After two washes with $\left(\mathrm{NH}_{4}\right)_{2} \mathrm{SO}_{4}$ of the same saturation, the precipitate was resuspended in $0 \cdot \mathrm{I} \mathrm{M}-\mathrm{NaCl} / \mathrm{I} 5 \mathrm{mM}-\mathrm{NaN}_{3}$ at onethird of the original fluid volume and dialysed until free of sulphate. The protein content in this partially purified, threefold concentrated preparation was $31 \mathrm{mg} \mathrm{ml} \mathrm{m}^{-1}$.

Quantitative immunoelectrophoresis. The procedure was a modification of the method of Axelsen, Krøll \& Weeke (1973). We found that the antibody carrier fraction of the mouse ascitic fluid moved slightly towards the anode at the $\mathrm{pH}(8 \cdot 6)$ recommended for quantitative immunoelectrophoretic examinations using rabbit gamma globulin. A lower $\mathrm{pH}(8 \cdot 3$ to $8 \cdot 4)$ was found to be more suitable for our study. Hence, all gel electrophoretic procedures were performed using barbital buffer $\mathrm{pH} 8 \cdot 4$, ionic strength $0 \cdot 02$. The buffer-gel connexions were made of agarose. To obtain more definite precipitin lines, $15 \mathrm{~mm}$-calcium lactate was added to the separation gels as recommended by Laurell (1965). Rocket immunoelectrophoresis was carried out in a $\mathrm{I} \cdot 5 \mathrm{~mm}$ layer of $\mathrm{I} \%(\mathrm{w} / \mathrm{v})$ agarose gel containing Io $\mu$ lantibody preparation $\mathrm{cm}^{-2}$, applying $\mathrm{I} \cdot 5 \mathrm{~V} \mathrm{~cm}^{-1}$ for $\mathrm{I} 8 \mathrm{~h}$ at $\mathrm{I} 5{ }^{\circ} \mathrm{C}$. Plates were $10 \times 10 \mathrm{~cm}$ and antigen samples were applied in $5 \mathrm{~mm}$ diam. circular wells. To reduce antibody consumption a microtechnique of crossed immunoelectrophoresis was used. Plates were $5 \times 5 \mathrm{~cm}$ and antigen samples were applied in slits. For the first-dimension electrophoresis, $8 \mathrm{~V} \mathrm{~cm}^{-1}$ was applied for $40 \mathrm{~min}$. The second-dimension run was carried out as described for the rocket immunoelectrophoresis. Immunoprecipitates were stained with Coomassie brilliant blue G-250.

\section{RESULTS}

All the mice in the first and the third groups completed the immunization schedule. One mouse in the second group developed a solid tumour due to an accidental intradermal injection of the Ehrlich cells and one in the fourth group died a week after the tumour injection due to an infection. The volume of fluid collected ranged from 3.5 to $20 \mathrm{ml}$ per mouse, the average being I $\cdot 4 \mathrm{ml}$. Every immune ascitic fluid reacted with the homologous antigen in the double diffusion test. The homologous titres of the first and the fourth pool were 32 ; those of the second and the third pool, 64. A maximum of two precipitin lines 


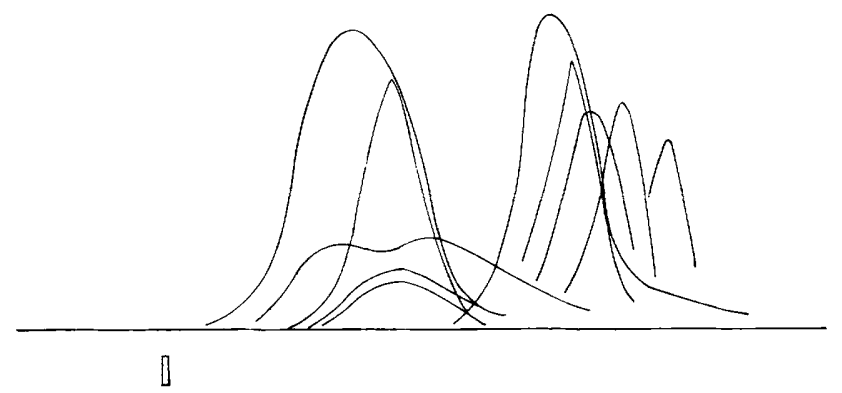

Fig. I. A tracing of the crossed immunoelectrophoresis of Fusarium culmorum antigens. The seconddimension gel contained partially purified ascitic antibodies against $F$. culmorum. (Anode to the right during the first-dimension run and at the top during the second-dimension run. Application slit, bottom left.)

was obtained by immunodiffusion of the immune ascitic fluid of the first, second and fourth pools. The immune ascitic fluid pool of the third group of mice gave three precipitin lines. Since the presence of antibodies to minor components is generally desired in mycoserology, this pool was chosen for further studies.

Rocket immunolectrophoresis was carried out to determine: (i) whether quantitative immunoelectrophoretic examinations could be accomplished using mouse ascitic antibodies; (ii) the appropriate antigen-antibody ratio to be applied for crossed immunoelectrophoresis; and (iii) what, if any, serological reaction could be observed using the culture medium as antigen. A twofold serial dilution of the antigen solution was prepared and $\mathrm{I} 6 \mu \mathrm{l}$ samples containing 25 to $400 \mu \mathrm{g}$ protein were subjected to rocket immunoelectrophoresis. In every case typical rockets of six to eight precipitin lines developed. On the basis of the rocket height, the appropriate antigen concentration for crossed immunoelectrophoresis was calculated to be $250 \mu \mathrm{g}$ protein. No reaction occurred with the potato/glucose medium.

By means of crossed immunoelectrophoresis, a total of I I individual precipitates could be distinguished. This is almost four times the number of antigens detected by immunodiffusion. Three of the I I precipitin lines were faint but they consistently appeared at the same position in replicate experiments. Figure $\mathrm{I}$ is traced from a typical slide.

\section{DISCUSSION}

When this work began, nothing was known about the suitability of immune mouse ascitic fluid for mycoserology and therefore different immunization schedules were tried. Hyperimmune ascitic fluid was prepared in every case, but the small number of mice used limits the conclusions that can be drawn about the superiority of any of the schedules. However, there are some interesting observations. An antibody level sufficient for serological tests can be elicited by the intraperitoneal administration of as little as $2 \times 2.5 \mathrm{mg}$ fungal protein. Although higher titres were generally obtained when $3 \times 2.5 \mathrm{mg}$ protein was given, the waiting period before booster inoculation appeared more important in this respect.

By means of the antigen-antibody crossed electrophoresis, I I antigens were demonstrated in homologous reactions. Axelsen (1973) demonstrated 78 to be present in Candida albicans. He used fivefold concentrated rabbit antibodies obtained after frequent and prolonged immunization procedures and the number of precipitin lines was in part due to use of two 
different immunizing antigen preparations. However, the number of detectable precipitates (antigens) is not a purpose in itself. Modifications in our immunization schedules will be necessary only if convincing serological differentiations between species cannot be achieved on the basis of about Io antigens.

The use of immune mouse ascitic fluid for crossed immunoelectrophoresis is economical. For the preparation of a $5 \times 5 \mathrm{~cm}$ immunoplate containing Io $\mu 1$ antibody solution $\mathrm{cm}^{-2}$, $0.2 \mathrm{ml}$ threefold concentrated immune ascitic fluid is needed. The peritoneal fluid of an average mouse is sufficient for 15 to 18 plates. Thus, antigens of more than 70 fungal strains can be tested in duplicate by using a pool of 10 mice. However, a limiting factor is the early death of mice inoculated with such a virulent neoplasm as Ehrlich's tumour. Repeated tappings of the fluid prolong the life of the mice, and therefore result in a larger volume of ascitic fluid, but this is not recommended with complex antigenic mixtures because qualitative and quantitative changes may occur in the antibody content of the different tappings. Larger ascites volumes may be obtained using a variant ascites cell subline such as Sarcoma I80/TG developed by Sartorelli, Fischer \& Downs (I966).

Our results indicate that ascitic fluid of mice immunized with water-soluble Fusarium culmorum antigens in Freund's complete adjuvant is a convenient source of antifungal antibodies. Further, the partially purified ascitic antibodies can be used for crossed immunoelectrophoresis. Together these techniques afford the possibility of economical comprehensive serotaxonomical studies on fungi.

We thank Assistant Professor K. Simon for his helpful advice on technical details of the tumour transplantation and Miss Mária Herbszt for technical assistance.

\section{REFERENCES}

ANACKeR, R. L. \& Munoz, J. (196I). Mouse antibody. I. Characterization and properties of antibody in mouse peritoneal fluid. Journal of Immunology 87, 426-432.

AXELSEN, N. H. (197I). Antigen-antibody crossed electrophoresis (Laurell) applied to the study of the antigenic structure of Candida albicans. Infection and Immunity 4, 525-527.

AXELSEN, N. H. (1973). Quantitative immunoelectrophoretic methods as tools for a polyvalent approach to standardization in the immunochemistry of Candida albicans. Infection and Immunity 7, 949-960.

Axelsen, N. H., Krøll, J. \& Weeke, B. (eds) (1973). A Manual of Quantitative Immunoelectrophoresis. Oslo, Bergen and Tromsø: Universitetsforlaget.

Bocharova, N. G. \& ANDreEva, Z. M. (I97I). Immunnȳe astsitnȳe zhidkosti k mikrobam B. bronchiseptica. Laboratornoe delo Ir, 683-685.

FEILD, J. \& KALTER, S. S. (1972). Volume production of reference seed viruses and immune ascitic fluids for six arboviruses. Applied Microbiology 23, 382-388.

GoA, J. (1953). A micro biuret method for protein determination. Determination of total protein in cerebrospinal fluid. Scandinavian Journal of Clinical and Laboratory Investigation 5, 218-222.

Herrmann, E. C. \& Engle, C. (I958). Tumour cell-induced mouse ascites fluid as a source of viral antibodies. Proceedings of the Society for Experimental Biology and Medicine 98, 257-259.

Kiriyama, K. \& Ohsumi, H. (I973). Antibody production in tumorous ascites of mice injected with plant viruses. Annals of the Phytopathological Society of Japan 39, 318-324. (in Japanese).

LAURELl, C.-B. (1965). Antigen-antibody crossed electrophoresis. Analytical Biochemistry ro, 358-361.

OUCHTERLONY, Ô. \& NiLSSON, L. Å. (1973). Immunodiffusion and immunoelectrophoresis. In Handbook of Experimental Immunology, and edn, pp. 19.I-19.39. Edited by D. M. Weir. Oxford: Blackwell Scientific Publications.

RedDecliff, J. M. \& Ludwig, E. H. (1966). Ascites fiuid from immunized mice as a source of plant virus antibodies. Applied Microbiology 14, 834-835.

Sartorelli, A. C., Fischer, D. S. \& Downs, W. G. (I966). Use of Sarcoma i8o/TG to prepare hyperimmune ascitic fluid in the mouse. Journal of Immunology 96, 676-682.

ScotT, H. A., KIM, K. S. \& DALE, J. L. (1969). Value of immune mouse ascitic fluid in plant virus serology. Phytopathology 59, 233-234.

Thoen, C. O. \& Karlson, A. G. (1970). Production of specific agglutinins for mycobacteria in peritoneal fluid of mice. Applied Microbiology 20, 847-848.

WEEKE, B. (1973). General remarks on principles, equipment, reagents and procedures. In $A$ Manual of Quantitative Immunoelectrophoresis, pp. I5-35. Edited by N. H. Axelsen, J. Krøll \& B. Weeke. Oslo, Bergen \& Tromsø: Universitetsforlaget. 